\title{
Commitment with Reference to Private College Teachers
}

\author{
Aisha Mary Joseph,Ambily A S
}

\begin{abstract}
The Scenario and environment in which organizations operate has undergone drastic change, owing to the advancement in technology and due to globalization. This change has affected the economy in many ways. Due to various economic conditions and unstable employment opportunities, the concept of Moonlighting has increased. Employees often take up a second job or business along with their main job for a variety of reasons. This is called Moonlighting. Employees when committed towards their organization are said to be more productive which indeed brings in result for the firm. With the introduction of Moonlighting the organizational commitment has further reduced. The education Industry is booming across the world and it generates large scale revenues and employment. Teachers all across the nation experience financial difficulty in their profession and are tend to practice moonlighting than any other employees. This paper tries to analyze the "Impact of Moonlighting" on the performance of teachers and whether it affects the Organizational Commitment of Teachers.
\end{abstract}

Keywords: Moonlighting, Organizational Commitment, Education Industry, Performance of Teachers.

\section{INTRODUCTION}

Human Resource Management is considered as the employee management with an emphasis on that employee as the asset of a business. In the current scenario, HRM is practically implemented in all the Sectors. The HR department in any company can yield high profit if used strategically, but unfortunately many sectors fail to implement it properly.

The Education industry is booming across the world and is considered as one of the most powerful instruments for reducing poverty and inequality. Human Resource Management is relatively ill-developed in education industry as it is difficult to implement and utilize it in a systematic and effective way (De Armond-2013; Smylic et.al -2004). Teachers are the ones who should be willing to continuously professionalize in their core areas by incorporating new insights into their daily practices and HRM can be seen as a solution for this. There is no doubt that education industry provides employment to mass structures but recently certain research have stated that the trend of moonlighting have gone high among the Teachers (Lambert 2003; Lambert and Hogan 2009)

Moonlighting is understood as the practice of working in a second job apart from the primary employment. Various employees contribute to the secondary market by spending additional hours either through taking up an additional job (secondary job) or through self-employment. Betts (2006) states that moonlighting was a continuous and existing trend which was found in both skilled and unskilled labor.

Why do people choose to Moonlight? The basic assumption is that it results from a constraint on hours worked on his/her primary job (Shishko and Rostker (1976), O' Connell (1979) and Krishnan (1990) due to economic reasons or other institutional factors the worker is unable to earn the desired income from his/her main job.

Many studies reports that moonlighting has increased the entrepreneurial abilities in teachers, and that it has brought in many creative ideas and innovation among people practicing moonlighting. As there are two sides in a coin, the impact of moonlighting may affect the organization in which the employee pursues his/her primary job. It is been stated through research findings that moonlighting directly effects the organizational commitment of employees which in turn results the productivity of the firm effecting the employer directly.

A business house is made or broken by the workforce of that organization (L.F Urwick). Therefore Human Resource is considered as the most important factors of production. Employees when committed to their organization are found more productive which leads to a higher quality of work produced (John Baldoni, 24 ${ }^{\text {th }}$ july,2013, Harvard Business Review). Organizational commitment can be described as a psychological state of employees which defines thier relationship with the organization and has implications whether to continue or discontinue membership in organization (Meyer \& Allen, 1991, p.67). "Employees who keep themselves engaged in their work and those who are committed to the same give companies vital competitive advantages including higher productivity and low rate of employee turnover"(Vance, 2006, p.1).

A study by Figlio(2002) states that the attitude, morale, motivation, efficacy, and job satisfaction of the teachers is considered essential and fundamental to the teaching occupation. The added desire of finding and pursuing a second job in addition to the first permanent job may affect the commitment factor of the employees. The present study would try to investigate the factors which lead teachers to Moonlight and whether moonlighting activities affect commitment level of teachers in their primary job. It also analyze the relationship between Demographic Variables and Moonlighting.
Revised Manuscript Received on April 12, 2019.

Aisha Mary Joseph, Research Scholar, Department of Commerce and Management, Amrita VishwaVidyapeetham, School of Arts and Science, Kochi, Kerala. India.

Ambily A S, Assistant Professor(Sr.Gr), Department of Commerce and Management, Amrita VishwaVidyapeetham, School of Arts and Science, Kochi.Kerala. India. 


\section{OBJECTIVES}

Following are the key research objectives of the study:

a) To study the factors that leads to moonlighting among the university Teachers.

b) To study the impact of moonlighting on the organizational commitment of the university teachers.

c) To find out the association between moonlighting and its factors

d) To find out relationship between Demographic Variables and Moonlighting

\section{LITERATURE REVIEW}

Sharon Brown, Sam.L.Sullivan, Bob Maninger, Moonlighting and Morale: The Impact on Educators Who Moonlight and How Classroom Teaching Suffers (Jan, 2017, The Journal of multidisciplinary graduate research, Volume1, Article 8, 1-17 states that the basic salary of the teachers should be increased by the concerned university as many of the teachers responded through the survey that they would quit Moonlighting Practices. In the upcoming future the universities should make their recruitment and retirement wing strong.

ConsolataMulokozi (2015 open university of Tanzania) Teachers moonlighting and its impact on their job performance: note that reasons high cost of living, insufficient salary, high demand for teachers, introduction of double sessions and less work load leads to Moonlighting practices in teachers. The moonlighting practices have negatively affected teachers' job performance on their primary job and they lacked personal development due to insufficient time. Government and private school owners should have a lending system to teachers so as to avert them from the options of borrowing from other financial institutions.

ShwetaSangwan: Managing Employee MoonlightingIssues and implications.( International Journal of scientific research and education- volume 2, issue 12,2014.) Many employees take up moonlighting for various reasons; the employer should not focus on stopping the employees from moonlighting but should prevent them from conflict of interest. The main concern of employers would be that will moonlighting activities should not hamper the organizational performance. Managers should follow an explicit policy on moonlighting practices. If employers need they may prohibit moonlighting but an employee-employer relationship extends beyond legal contracts. To maintain a harmonious relation, a well crafted moonlighting policy will go a long way.

Puja Khatri and Khushboo.: A study of Organizational commitment and moonlighting practices of SME employees in Delhi-NCR (Global Journal of Finance and Management. ISSN 0975-6477 Volume 6, Number 6(2014), pp.535-544, Research India) The small and medium enterprises lack some unique features which the MNCs possess like information and technology, finance, and most importantly concrete HRD programs. Such programs makes employees understand their rights and boost their confidence in work, which in turn will positively affect their performance and organization. The owners or entrepreneurs should address the basic necessities of employees as it would increase the commitment of employees.

Maslow's Hierarchy of needs theory (1943): Abraham Maslow, in his classic paper, outlined elements of an overall theory of motivation. This theory depicts that human beings are want animals. The managers should identify the need level at which the employee is surviving and then those needs can be used as a push or drive for motivation. In such case, whenever teachers lower level of need is satisfied that could be a motivation to seek higher level of needs and therefore in such a situation teachers may think about moonlighting.

\section{RESEARCH METHODOLOGY}

This research initiative studies the Moonlighting practices and the level of organizational Commitment of Teachers towards their organization. It is purely a descriptive based study.

\section{DATA SOURCES}

Both Primary and Secondary Sources have been carried out for this study.

Secondary Data: The Secondary data was been obtained from Journals, Books, Research Articles, Websites, Reports etc.

Primary Data: The primary data has been carried out with a self constructed questionnaire. The questionnaire had two parts $\mathrm{A}$ and $\mathrm{B}$, where part A purely focused on the demographic details of the respondents and part B mapped the perception of respondents regarding the variables of Moonlighting and Organizational Commitment. The questionnaire was constructed on a five point Likert Agreement Scale to measure the responses on the decided variable. The entire populations of 30 from two private colleges were taken for the study. For the purpose of getting output, statistical tools like Chi-Square, Pearson's Correlation, Regression and Descriptive Statistics were used with the support of SPSS software.

\section{SCOPE OF THE STUDY}

This Research was conducted in the Private colleges of Alapuzha District. The Research focused on the Factors which leads to Moonlighting and their relationship with moonlighting practices and their Impact on the Organizational Commitment.

\section{ANALYSIS AND INTERPRETATION}

\section{Relationship between Gender of the respondents and Moonlighting activities}

This study analyses the relationship between the gender of the respondents and the Moonlight practice of teachers. For this purpose, chi-square test is used. For easier understanding,

Demographic variables are categorized into two groups such as personal profile and Moonlighting practice

Table: Relationship between Gender of the respondents and Moonlight activities 
Null Hypothesis-I: There is no significance difference

Null hypothesis-II: There is no significance Difference between gender of the respondents and the factors affecting moonlight practice of college teachers between gender of the respondents and the Moonlighting practice of college teachers

\begin{tabular}{|l|l|l|l|l|}
\hline sl no. & Particular & $\begin{array}{l}\text { chi-square } \\
\text { value }\end{array}$ & DF & Sig \\
\hline 1 & Financial Status & 10.096 & 11 & 0.522 \\
\hline 2 & Salary/Income. & 12.692 & 8 & 0.123 \\
\hline 3 & Job Performance & 15.288 & 10 & 0.122 \\
\hline 4 & Job Autonomy & 16.364 & 9 & 0.06 \\
\hline 5 & Job Security. & 8.365 & 8 & 0.399 \\
\hline 6 & Employee Welfare & 5.455 & 8 & 0.708 \\
\hline 7 & Management Effectiveness: & 8.242 & 10 & 0.605 \\
\hline 8 & Motivation: & 18.462 & 10 & 0.048 \\
\hline 9 & Work Pressure/ Job Stress & 10.529 & 9 & 0.309 \\
\hline 10 & Moon light practice, & 25.673 & 27 & 0.537 \\
\hline 11 & organizational commitment & 30 & 27 & 0.314 \\
\hline
\end{tabular}

\section{INTERPRETATION}

The above table presents the results of chi-square along with their significance level. If the $\mathrm{p}$ value is less than 0.05 , then the variables are associated. Chi-square result reveals that variables such as Financial Status, Salary/Income., Job Performance, Job Autonomy Job Security, Employee Welfare, Management Effectiveness, Motivation, Work Pressure/ Job Stress, Moon light practice and organizational commitments are not significantly associated with the Gender of the respondents.

\begin{tabular}{||l|l|l|l||}
\hline sl no. & Particular & $\begin{array}{l}\text { Pearson } \\
\text { correlation }\end{array}$ & Sig \\
\hline 1 & Financial Status & 0.523 & 0.003 \\
\hline 2 & Salary/Income. & 0.523 & 0.003 \\
\hline 3 & Job Performance & 0.206 & 0.275 \\
\hline 4 & Job Autonomy & 0.623 & 0.000 \\
\hline 5 & Job Security. & 0.699 & 0.000 \\
\hline 6 & Employee Welfare & 0.694 & 0.000 \\
\hline 7 & Management Effectiveness: & 0.693 & 0.000 \\
\hline 8 & Motivation: & 0.548 & 0.000 \\
\hline 9 & Work Pressure/ Job Stress & 0.724 & 0.000 \\
\hline 11 & organizational commitment & 0.943 & 0.000 \\
\hline
\end{tabular}

\section{ANALYSIS}

From the above correlation matrix it can be seen that there exist a positive correlation between moonlighting activities and financial status. The $\mathrm{P}$ value is 0.003 . Since the $\mathrm{P}$ value is less than 0.05 , it can be interpreted that there is a
Null Hypothesis-I: There is no Association between Factors affecting moonlight practice and theMoonlighting practices of college Teachers.

\section{CORRELATION BETWEEN MOONLIGHTING ACTIVITES AND FACTORS AFFECTING MOONLIGHTING ACTIVITIES}

between

correlation

ities and

Salary/Income. The $\mathrm{P}$ value is 


\section{Commitment With Reference To Private College Teachers}

0.003. Since the $P$ value is less than 0.05 , it can be interpreted that there is a significant relationship between moonlighting activities and Salary/Income.

It can be seen from the above that there exist a weak positive correlation between moonlighting activities and Job Performance. The $\mathrm{P}$ value is 0.275 . Since the $\mathrm{P}$ value is more than 0.05 , it can be interpreted that there is not significant relationship between moonlighting activities and Job Performance.

The above table shows that the moonlighting activities and job autonomy is positively correlated with the correlation co efficient of 0.623 . Here the $\mathrm{P}$ value is 0.000 . Since the $\mathrm{P}$ value is less than 0.05 , it can be interpreted that the moonlighting activities and job autonomy are significantly correlated.

It can be seen from the above that there exist a high positive correlation between moonlighting activities and job security. The $P$ value is 0.000 . Since the $P$ value is less than 0.05 , it can be interpreted that there is a significant relationship between moonlighting activities and job security.

It can be seen from the above that there exist a high positive correlation between moonlighting activities and employee welfare. The $\mathrm{P}$ value is 0.000 .Since the $\mathrm{P}$ value is less than 0.05 , it can be interpreted that there is a significant relationship between moonlighting activities and employee welfare.

It can be seen from the above that there exist a high positive correlation between moonlighting activities and Management Effectiveness. The $\mathrm{P}$ value is 0.000. Since the $\mathrm{P}$ value is less than 0.05 , it can be interpreted that there is a significant relationship between moonlighting activities and Management Effectiveness.

The above table shows that the moonlighting activities and motivation is positively correlated with the correlation co efficient of 0.548 . Here the $\mathrm{P}$ value is 0.000 . Since the $\mathrm{P}$ value is less than 0.05 , it can be interpreted that the moonlighting activities and motivation are significantly correlated.

It can be seen from the above that there exist a high positive correlation between moonlighting activities and Work Pressure/ Job Stress. The P value is 0.000. Since the P value is less than 0.05 , it can be interpreted that there is a significant relationship between moonlighting activities and Work Pressure/ Job Stress.

The above table shows that the moonlighting activities and organizational commitment is highly positively correlated with the correlation co efficient of 0.943 . Here the $P$ value is 0.000 . Since the $P$ value is less than 0.05 , it can be interpreted that the moonlighting activities and organizational commitment are significantly correlated.

The highest value of Pearson co efficient of correlation is between organizational commitment and moonlighting activities. The co efficient of correlation is 0.943 followed by Work Pressure/ Job Stress (0.724), Job Security (0.699), Employee Welfare (0.694), Management Effectiveness (0.693) etc. The correlation analysis reveals that the moonlighting activities and factors affecting moonlighting activities are positively related with each other.

\section{DESCRIPTIVE STATISTICS RESULTS}

\begin{tabular}{|l|l|l|l|l|l|l|}
\hline \multicolumn{2}{|l|}{ Descriptive Statistics } & & & & \\
\hline & N & Mean & & $\begin{array}{l}\text { Std. } \\
\text { Deviation }\end{array}$ & Skewness & Kurtosis \\
\hline & Statistic & Statistic & Std. Error & Statistic & Statistic & Statistic \\
\hline organizational commitment & 30 & 3.69875 & 0.083236 & 0.455904 & -0.63272 & 0.870716 \\
\hline Management Effectiveness: & 30 & & & & & \\
\hline Motivation: & 30 & 3.766667 & 0.116173 & 0.636306 & -0.41584 & 0.961049 \\
\hline Moonlighting Activities & 30 & 3.574259 & 0.067844 & 0.371599 & -0.67705 & 0.968252 \\
\hline stress & 30 & 3.766667 & 0.1492 & 0.8172 & -0.49315 & 0.193289 \\
\hline
\end{tabular}

\section{ANALYSIS}

Among the factors affecting moonlighting activities it can be interpreted from the above that the mean value of Motivation and stress is the highest and the same for management Effectiveness is the lowest. The highest and the lowest values were 3.766667 and 3.375 respectively. The standard deviation was high for stress and the same for Moonlighting Activities was the lowest. The descriptive static analysis shows that all the factors are negatively skewed. The kurtosis was high for Management Effectiveness and was low for stress.

\section{REGRESSION}

Ho: There is no relationship between moonlighting activates and organizational commitment. 
H1: There is relationship between moonlighting activates and organizational commitment.

\begin{tabular}{|c|c|c|c|c|c|c|}
\hline \multirow[b]{2}{*}{ Model } & & \multicolumn{2}{|c|}{ Unstandardized Coefficients } & \multirow{2}{*}{$\begin{array}{l}\text { Standardized } \\
\text { Coefficients } \\
\text { Beta }\end{array}$} & \multirow[b]{2}{*}{$\mathrm{T}$} & \multirow[b]{2}{*}{ Sig. } \\
\hline & & $\mathrm{B}$ & Std. Error & & & \\
\hline \multirow[t]{2}{*}{1} & (Constant) & .732 & .192 & & 3.824 & .001 \\
\hline & commit & .768 & .051 & .943 & 14.948 & .000 \\
\hline
\end{tabular}

A Dependent Variable: moonlighting activities

The equation shows that the coefficient for organizational commitment is 0.943 . The coefficient indicates that organizational commitment plays a very important role in moonlighting activates.

Here the $\mathrm{P}$ value is less than 0.05 and it indicates that moonlighting activates and organizational commitment is associated. There is a significant relationship between moonlighting activates and organizational commitment.

\section{FINDINGS}

1. Chi-square result reveals that variables such as Financial Status, Salary/Income., Job Performance, Job Autonomy Job Security, Employee Welfare, Management Effectiveness, Motivation, Work Pressure/ Job Stress, Moon light practice and organizational commitments are not significantly associated with the Gender of the respondents.

2. The highest value of Pearson co efficient of correlation is between organizational commitment and moonlighting activities. The co efficient of correlation is 0.943 followed by Work Pressure/ Job Stress (0.724), Job Security (0.699), Employee Welfare (0.694), Management Effectiveness (0.693) etc. The correlation analysis reveals that the moonlighting activities and factors affecting moonlighting activities are positively related with each other. The

3. There is a significant relationship between moonlighting activities and factors affecting moonlighting activities except job performance.

4. The mean value of Motivation and stress is the highest and the same for management Effectiveness is the lowest.

5. The standard deviation was high for stress and the same for Moonlighting Activities was the lowest.

6. The descriptive static analysis shows that all the factors are negatively skewed.

7. The kurtosis was high for Management Effectiveness and was low for stress.

8. There is a significant relationship between the activities related with moonlighting and Organizational commitment.

\section{RECOMMENDATIONS}

$>$ The negative effect of moonlighting is more evident in terms of formation of an underground economy. Therefore appropriate policy is required to combat this behavior of moonlighting.

$>$ The deserving policy in this situation is to prevent conflict with the moonlighting behavior of employees and provide them with more flexibility (lesser control) in their primary job.

$>$ The combination of enhancing flexibility of working hour and increasing the basic salary rate is useful to battle against moonlighting.

$>$ The Organizations should make their HRD programs strong as it creates awareness among the employees regarding their rights and it will in turn boost up their loyalty.

$>$ The governments may make payments to employees via electronic systems rather than giving cash by hand.

$>$ The employers should inculcate a well drafted contract which should include an express term to prohibit the employee from taking up a second job. Such contracts should contain an express term which instructs the employee to completely devote his/her time and attention to the business of the employer during the normal working hours. Using the organizations time for any other business or work would end up in the breach of the clause.

$>$ The government along with the ministry of education, training institutions, and the owners of private educational institutions should ensure that the teachers are provided with best quality terms and services, also the basic salary and remuneration of every teacher should be attractive as per the qualification possessed by each individual. This will indeed upgrade the teaching profession and shall be helpful in cutting down the number of moonlighters.

\section{CONCLUSION}

Moonlighting has now become a common practice. Moonlighting was one of the unattended areas until 2000s, but recently it has gained the attention of people as the number of moonlighters has

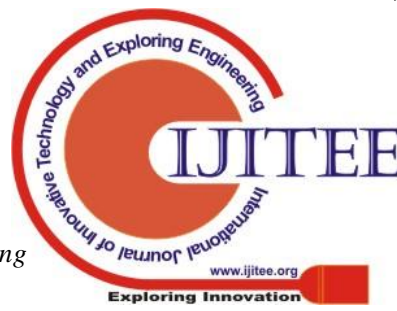




\section{Commitment With Reference To Private College Teachers}

increased. Moonlighting is now considered as an important factor in the labor market analysis. Moonlighting does have different dimensions. When some features of Moonlighting are found positive and welcoming, like every coin has 2 sides practicing Moonlighting also has negative impacts. It is often found out that moonlighters escape from paying income tax to the government for the salary received from the second job and this can increase underground activities in the economy. Anti-Moonlighting policies are to be implemented by every organization in order to prevent such practices. In order to keep moonlighting at bay, we have discussed several policies against moonlighting. Electronic payment system, Job Autonomy, increase in the basic salary, concrete HRD programs, contract clause etc. may be helpful to curb the adverse effects of moonlighting. Unless these policies are practically implemented, moonlighting policies may continue to be in hike.

\section{LIMITATIONS OF THE STUDY}

- The study is limited to the Education Industry situated in Kerala alone that too from Alapuzha District alone.

- Due to time constraints the study was limited to teachers.

- The study is limited by the limitations of the Analytical tools used for the analysis of the data in the study.

- $\quad$ The sample size is limited to 30 .

\section{REFERENCES}

1. Fred Luthans(2013) Organizational Behavior- An Evidence Based Approach, MCGraw Hill Education (India) Private Limited, New Delhi.

2. Puja Khatri and Khushboo. A Study of Organizational Commitment and Moonlighting Practices of SME Employees in Delhi-NCR Global Journal of Finance and Management. ISSN 0975-6477 Volume 6, Number 6(2014), pp.535-544, Research India.

3. http://www.managementstudyguide.com/maslows-hierarchyneeds-theory.html.

4. Sharon Brown, Sam.L.Sullivan, Bob Maninger, Moonlighting and Morale: The Impact on Educators Who Moonlight and How Classroom Teaching Suffers (Jan, 2017, The Journal of multidisciplinary graduate research, Volume1, Article 8, 1-17.

5. ConsolataMulokoziTeachers' Moonlighting And Its Impact On Their Job Performance In Dar Es Salaam Region Secondary Schools. (2015 open university of Tanzania)

6. ShwetaSangwan: Managing Employee Moonlighting-Issues and implications. (International Journal of scientific research and education- volume 2 , issue 12,2014 .)

7. www.investopedia.com.

8. http://www.projectguru.in/publications/moonlighting-avoid/Moonlighting and Implementing policies that prevent it.

9. http://www.personneltoday.com/hr/moonlighting-how-tohandle-employees-working-additional-jobs/

10. Robert Alley and Marcus Ballenger-Teacher Education Quarterly, vol.20, No.4, Working with Teachers and Student Teachers (Fall 1993), pp. 107-113(7 pages),Published by Caddo Gap press- Student Teacher Moonlighting: A Questionable Practice.

11. Richard Wisniewski and Paul Kleine- Teacher Moonlighting: An Unstudied Phenomenon The Phi Delta Kappan, Vol.65, No.8(Apr., 1984), pp. 553-555 (3 pages).

12. Jacob Ninoo, KwabenaNkansahDarfor, Isaac Koomson, and Abigail Arthur-AGDI Working Paper WP/16/006
Employment Security and Workers' Moonlighting Behavior in Ghana, April 2016.

13. MohdZdikri bin MdSabron\&Alizabinti Abu Hassim MOONLIGHTING: FACTOR AFFECTING JOB PERFORMANCE AMONG STAFF AT KLANG VALLEY PUBLIC HOSPITAL, e-Proceeding of the Social Sciences Research(ICSSR 2016)

14. MohdZdikri bin MdSabron\&Alizabinti Abu Hassim- Journal of Administrative Science, Special Edition: ICOPS, JAS, Vol.15, Issue 3, 2018- A Study on The Perception of Moonlighting Practices among The Employees of Public Hospitals in Klang Valley.

15. Estelle Hepton- MOONLIGHTING IN WAIKIKI, Reprinted from ILR RESEARCH, Vol.7 No.1, Spring 1961. 